\title{
Impacts of Minimum Wage Policy on Wage Distributions in Urban China: Comparison between Public and Private Sectors
}

\author{
Xinxin Ma \\ Institute of Economic Research, Hitotsubashi University, Tokyo, Japan \\ Email:maxx@ier.hit-u.ac.jp
}

Received 5 July 2016; accepted 31 July 2016; published 3 August 2016

Copyright (C) 2016 by author and Scientific Research Publishing Inc.

This work is licensed under the Creative Commons Attribution International License (CC BY).

http://creativecommons.org/licenses/by/4.0/

(c) (i) Open Access

\begin{abstract}
Using Chinese Household Income Project survey (CHIP) data, this study analyzes the impact of the Minimum Wage (MW) policy on average wage and wage distribution in urban China in the 19931995, the 1998-2002, and the 2007-2013 periods, and compared the MW effects between public and private sectors. Several major conclusions emerged from this study. First, comparatively, the overall impact of the MW on average wage in the 1993-1995 period is greater than the effect of the MW level on the average wage. Second, the MW effects on average wage exist in both the public and private sectors. However, holding the other factors consistent, the MW effect on average wage is greater for the private sector than for the public sector. Third, the overall effects of MW level on the low-wage group increased in the 2007-2013 period. Fourth, the effects of MW on wage distribution are greater for the private sector than for the public sector in the three periods. Holding the other factors consistent, the impact of MW on the low-wage group for the private sector increased greatly than for the public sector in the 2007-2013 period. Fifth, decomposition results indicated that the differences of distribution proportions, in regions with different MW levels between the public and private sectors helped reduce the wage gaps, as did the MW effects on wage, which were greater for the private sector than for the public sector in the 1993-1995 and 20072013 periods.
\end{abstract}

\section{Keywords}

Minimum Wage Policy, Wage Distribution, Public Sector, Private Sector, Urban China

\section{Introduction}

The rationale behind the Minimum Wage (MW) policy is to increase the wage level for low-income group re- 
duce their poverty level and narrow income inequality between high- and low-wage groups. Thus, the MW implementation is an important labor policy in both developing and developed countries.

In China, income inequality increased during the economic transition period. Along with marketization reform progress, the Chinese government also implemented the MW policy. This policy addressed "market failure" caused by firms that set lower than equilibrium wages. MW was first promulgated as a law-Enterprise's Minimum Wage Regulations-in 1993. The MW level is mainly determined by the regional government. In 2004, the government published a new MW regulation to enforce the implementation of MW policy in whole of China; therefore, there was a large increase in MW level since 2004.

In addition, although the labor market is reformed by Chinese government since 1978, it is pointed out that the wage determine systems are different between the public sector and the private sector; there exits wage gap between these two sectors even if worker's human capital factors are consistent (Chen, Demurger, \& Fournier, 2005; Zhang Juwei \& Xue Xinxin, 2008; Ye Lingxiang, Li Shi, \& Luo Chuliang, 2011; Demurger, Li, \& Yang, 2012; Ma, 2015, 2016). Thus, if the MW effects exist, the effects may be different by these two sectors.

There are some empirical studies on the effects of MW on employment, wage gaps, and income inequality for developed countries, but hardly any empirical studies to understand the effects of MW on wage distribution in China. Particularly, there is no empirical study on the comparison between the public sector and the private sector. In this study, we provide numerical evidence to these issues.

Concretely, this study attempts to answer the following questions through an empirical analysis using microdata from Chinese Household Income Project survey (CHIPs). First, does the MW affect wage levels? Second, if it does, is the effect of MW on wage different by wage distribution? Third, is the MW effect on wage different for the public and the private sector? Fourth, does MW affect wage gaps between the public and private sectors? Considering that the MW primarily affects low-income groups, we employ different models to conduct an analysis on both average wage and different wage percentiles.

\section{Literature Review}

For the developed countries, Card and Krueger (1995), Neumark (2001), Gindling and Terrell (2005), Neumark, Cunningham and Siga (2006), Hohberg and Lay (2015) utilized OLS (ordinary least squares) and QR (quantile regression) models to analyze the effects of MW on average wage and different percentile wage groups based on the cross section data and time-series data ${ }^{1}$.

Considering empirical studies on the issue for China, Jia Peng and Zhang Shiwei (2013) utilized the Neumark, Schweitzer, Wascher (2004) model (which is names as Neumark, et al. 2004) to analyze the MW effect throughout wage distribution in China using 1997-2009 CHNS (Chinese Health and Nutrition Survey) survey data. They found that the MW effect increase can reach to 1.00 - 1.25 times of the MW level on wage distributions. Di Junpeng and Han Qing (2015) utilized OLS (Ordinary Least Squares), QR (Quantile Regression) and DID (Difference in Difference) models to analyze the effect of MW on urban residents income using 1996-2010 CHNS, and revealed that when the MW level increases per $1 \%$, the average wage will increase by $0.6 \%$, and the affect mainly concentrates in the low-income group. Moreover, they pointed out that the MW specially provide protection for the elderly and low-skill workers based on the results by the DID method analysis. Ma Shuang, Zhang Jie, \& Zhu Xi (2012) utilized Chinese manufacturing firm-level data and city-level MW from 1997 to 2007 to analyze the effect of MW on the average wage in firms by OLS, and found that if the MW increase by $10 \%$, the average wages in firms would pick up by $0.4 \%-0.5 \%$.

The main contributions of this study are as follows: First, considering the MW compliance problem in China, using CHIP 1995, 2002, 2007 and 2013 data, the effects of MW policy are analyzed for the three periods-the MW beginning period (1993-1995), the MW implementation period (1998-2002), and the MW enforcement period (2007-2013). This shows the disparities of MW effects on wage distribution, which is perhaps caused by the government's enforcement behaviors. Second, considering that the wage determinants system and the MW policy compliance situations are different for the public and private sectors and that the proportions of low-wage groups may be different for these two sectors, the effect of MW on wage distribution might differ for the public and private sectors. Using the subsamples, the comparison between these two sectors is also employed in this study.

\footnotetext{
${ }^{1}$ The analysis method based on panel data, please see Neumark, Schweitzer and Wascher (2004), Neumark, Cunningham and Siga (2006),
} Dinkelman and Ranchhod (2012), Bhorat, Kanbur, and Stanwix (2014). 


\section{Methodology and Data}

\subsection{Model}

1) The model for MW Effects on average wage

The OLS model for MW effects on average wage is represented with the Equation (1.1).

$$
\ln W_{i j t}=a_{t}+\beta_{1} \ln M W_{j t}+\beta_{2} X_{i j t}+\varepsilon_{i j t}
$$

In the Equation (1.1), $i$ represents individual workers, $t$ represents periods and $j$ represents regions. $\ln W$ is the logarithmic value of wage, $\ln M W$ is the logarithmic value of the MW maximum value, $X$ is other variables affecting wages (such as education and work experience year as a proxy for human capital, male, occupation, industry dummy, public sector dummy, and year dummy), $a$ is a constant, $\varepsilon$ is an error term and $\beta_{1}$, $\beta_{2}$ represent the estimated coefficient of variables. The coefficients of $\ln M W\left(\beta_{1}\right)$ show the effect of MW on average wage. If $\beta_{1}$ is statistically significant, it indicates that the implementation of MW affects average wage.

Comparing the difference between the public and private sectors in terms of the MW effect, public sector dummy is utilized in the OLS model, it is represented with the Equation (1.2). In the Equation (1.2), Pub represents public sector dummy, $\ln M W * P u b$ is the interaction term- $\ln M W$ and $P u b$. If $\beta_{3}$ is a negative value, and it is statistically significant, it indicates that the MW effect on average wage is greater for the private sector than for the public sector and vice versa.

$$
\ln W_{i j t}=a_{t}+\beta_{1} \ln M W_{j t}+\beta_{2} P u b+\beta_{3} \ln M W * P u b+\beta_{4} X_{i j t}+v_{i j t}
$$

2) The model for MW effects on wage distribution

To see the effects of the MW by wage distribution, we adopt the Quantile Regression model (Koenker \& Baset, 1978), which can be expressed as:

$$
\begin{gathered}
\min \left[\sum_{h_{1} ; \ln W_{i j} \geq \beta H_{i j}} \theta\left|\ln W_{i j}-\beta(\theta) H_{i j}\right|+\sum_{h_{0}: \ln W_{i j}<\beta H_{i j}}(1-\theta)\left|\ln W_{i j}-\beta(\theta) H_{i j}\right|\right] \\
\rho_{\theta} \in(0,1)
\end{gathered}
$$

In Equation (2), $i$ represents individual workers, and $\theta$ represents percentile of wages (1 percentile is expressed as $1^{\text {st }}$ ). The equation's other variables are the same as those of Equation (1). $\rho_{\theta}($.$) is a check (or indi-$ cator) function. $H$ indicates $\ln M W$, the public sector dummy $P u b$, the interaction term of $\ln M W$ and $P u b$, and $X$ presented in Equation (1.1) and (1.2).

The QR model is designed for estimation using the optimal method, which minimizes the two error terms. The coefficients of $\ln M W\left(\beta_{1}(\theta)\right)$ show the MW effect on wage by the wage distributions. If $\beta_{1}(\theta)$ is statistically significant, it indicates that the implementation of MW policy affects wage distribution. The coefficients of interaction terms - $\ln M W(\theta)$ and $P u b$, are also utilized to compare the MW effects on wage distribution between the public and private sectors.

3) The model for MW effects on wage gaps between the public and private sectors

Based on wage functions by OLS, the Oaxaca-Blinder decomposition model (Oaxaca, 1973; Blinder, 1973) can be derived as equations (3.1), (3.2).

$$
\begin{gathered}
\ln \bar{W}_{p u b}-\ln \bar{W}_{p r i}=\left(\bar{X}_{p u b}-\bar{X}_{p r i}\right) \beta_{p u b}+\bar{X}_{p r i}\left(\beta_{p u b}-\beta_{p r i}\right) \\
\ln \bar{W}_{p u b}-\ln \bar{W}_{p r i}=\left(\bar{X}_{p r i}-\bar{X}_{p u b}\right) \beta_{p r i}+\bar{X}_{p u b}\left(\beta_{p r i}-\beta_{p u b}\right)
\end{gathered}
$$

In equations (3.1), (3.2), pub represents public sector, pri represents private sector, $\ln \bar{W}$ is the logarithm of the average wage, $\bar{X}$ is the average values of variables, and $\beta_{p u b}$ and $\beta_{p r i}$ represent the estimated coefficients resulting from the wage functions of the public and private sectors, respectively.

$\left(\bar{X}_{p u b}-\bar{X}_{p r i}\right) \beta_{p u b}$ and $\left(\bar{X}_{p r i}-\bar{X}_{p u b}\right) \beta_{p r i}$ represent the wage gap resulting from a difference between the public and private sectors in the individual characteristics factors-including human capital (e.g. education, experience years, occupation and industry), the MW level and regional distribution, $\bar{X}_{p r i}\left(\beta_{\text {pub }}-\beta_{\text {pri }}\right)$ and $\bar{X}_{p u b}\left(\beta_{p r i}-\beta_{p u b}\right)$ represent the wage gap caused by the unexplained differentials, including different wage system and discriminations. 


\subsection{Data}

CHIPs 1995, CHIPs 2002, CHIPs 2007 and CHIPs 2013 are utilized for the analysis. These data are gained from the four surveys of the CHIPs (Chinese Household Income Project Survey) conducted by NBS (National Bureau of Statistics), Institute of Economic, CASS (Chinese Academy of Social Science) and Beijing Normal University in 1996, 2003, 2008 and 2014, including respective information about employment and wages of urban residents.

Using retrospective survey data of income in CHIPs 1995 and CHIPs 2002, and the survey data in CHIPs 2007 and CHIPs 2013, we can conduct time series data sets for the 1993-1995 period, the 1998-2002 period, and the 2007-2013 period. Because there are design similarities of the data in the questionnaire, we can use the same information for analysis for all three periods-MW beginning period (1994-1995), MW performed period (19982002), MW enforcement period (2007-2013).

CHIP surveys cover the representative regions in China, including Beijing, Shanxi, Liaoning, Jiangsu, Anhui, Guangdong, Henan, Hubei, Sichuan, Yunnan, and Gansu in 1995, Beijing, Shanxi, Liaoning, Jiangsu, Anhui, Guangdong, Henan, Hubei, Sichuan, Chongqi Yunnan, and Gansu in 2002, Beijing, Shanxi, Liaoning, Jiangsu, Anhui, Guangdong, Henan, Hubei, Sichuan, Chongqi, Yunnan, Gansu, Shanghai, Zherjiang, Fujian, Hunan in 2007 and 2013. Utilizing the information of the regions, we merge the MW level ${ }^{2}$ based on the National Minimum Wage Dataset to the CHIP survey data to construct the new dataset-including the individual level data and the regional level MW data for the analysis.

\subsection{Variable Setting}

The wage is defined as the total earnings from work (called "the total wage") $)^{3}$. Here, it comprises the basic wage, cash subsidy, and no cash subsidy ${ }^{4}$. We use the CPI in 1995 as the standard, and adjust the nominal monthly wage and nominal MW level in every year.

The analytic objects of this paper are employees, excluding the self-employer and the unemployed. Considering the retirement system of the state-owned sector, to reduce the effect of that system on the analysis result, the analytic objects are limited in the groups to between the ages of 16 and 60 .

In the wage function, the explained variable is the logarithm of the monthly wage, and the explaining variables are the variables likely to affect the wage, such as schooling years, experience years ${ }^{5}$, public sector dummy variable ${ }^{6}$, occupation dummy variable ${ }^{7}$, industry dummy variable ${ }^{8}$, and region dummy variables (the East, Central and West Regions).

\section{Descriptive Statistics of the Data}

\subsection{Descriptive Statistics of Variables}

The statistical description of variables for the three periods is summarized in Table 1. It showed that the individual characteristic and variable distributions in the occupation, industry, and regions are different for the public and private sectors.

\footnotetext{
${ }^{2}$ Based on the MW policy, the MW level is adjusted once every one or two years, according to many factors, such as the lowest regional living cost, consumer price index of urban residents, social insurance, the housing fund that individual workers are paid, regional average wage level, status of economic development, and employment status. The local government (province or city government) adjusts the MW level; as a result, there are regional disparities in MW levels.

${ }^{3}$ According to the MW policy published in 1993, the main content of the MW consist of total earnings from work (except the overtime subsidy), any risk job subsidy and social security subsidy. We cannot distinguish the detail subsidy items from CHIP data. We also made an analysis using the basic wage. The results are similar to the results using the total wage. Therefore, we show the results using total wage in this paper. The earnings data does not include unofficial payments, and if such payments are more likely to be made to men, the gender wage gap will be underestimated.

${ }^{4}$ Here, no cash subsidy is the goods which is provided by the firm or the organization in the public sector. For example, the workers receive the food, the clothes and the other goods in the festivals such as the spring festivals (the Chinese New Year) from the state-owned enterprises (SOEs). These no cash subsidy in the CHIP survey are calculated by the market prices and they are utilized in the analysis as a part of wages.

${ }^{5}$ Experience years = age-6-schooling years.

${ }^{6}$ It is equal to 1 if the individual is working in the government organization, public organization (Shiye Danwei) and state-owned enterprises, it is equal to 0 if not.

${ }^{7}$ It is equal to 1 if the individual is working as blue-color worker (such as manual job worker), it is equal to 0 if not.

${ }^{8}$ It is equal to 1 if the individual is working in manufacturing industry, it is equal to 0 if not.
} 
Table 1. Statistical description of variables.

\begin{tabular}{|c|c|c|c|c|c|c|}
\hline & \multicolumn{2}{|c|}{ Total } & \multicolumn{2}{|c|}{ Public sector } & \multicolumn{2}{|c|}{ Private sector } \\
\hline & Means & S.D. & Means & S.D. & Means & S.D. \\
\hline \multicolumn{7}{|c|}{ Panel A: 1993-1995 } \\
\hline Sectors: public sector & 0.807 & 0.395 & & & & \\
\hline Male & 0.505 & 0.500 & 0.532 & 0.499 & 0.390 & 0.488 \\
\hline Schooling year & 11 & 3 & 11 & 3 & 9 & 3 \\
\hline Experience year & 28 & 10 & 28 & 10 & 28 & 10 \\
\hline Occupations: blue-color workers & 0.381 & 0.486 & 0.348 & 0.476 & 0.520 & 0.500 \\
\hline Industries: manufacturing & 0.399 & 0.490 & 0.372 & 0.483 & 0.516 & 0.500 \\
\hline \multicolumn{7}{|l|}{ Regions } \\
\hline West region & 0.262 & 0.439 & 0.263 & 0.440 & 0.256 & 0.436 \\
\hline Central region & 0.272 & 0.445 & 0.284 & 0.451 & 0.221 & 0.415 \\
\hline East region & 0.467 & 0.499 & 0.453 & 0.498 & 0.523 & 0.499 \\
\hline Observations & 37,658 & & 30,391 & & 7,267 & \\
\hline \multicolumn{7}{|c|}{ Panel B: 1998-2002 } \\
\hline Sectors: public sector & 0.667 & 0.471 & & & & \\
\hline Male & 0.556 & 0.497 & 0.578 & 0.494 & 0.511 & 0.500 \\
\hline Schooling year & 12 & 3 & 12 & 3 & 11 & 3 \\
\hline Experience year & 29 & 10 & 29 & 10 & 28 & 10 \\
\hline Occupations: blue-color workers & 0.286 & 0.452 & 0.278 & 0.448 & 0.303 & 0.460 \\
\hline Industries: manufacturing & 0.254 & 0.435 & 0.216 & 0.412 & 0.328 & 0.470 \\
\hline \multicolumn{7}{|l|}{ Regions } \\
\hline West region & 0.265 & 0.441 & 0.278 & 0.448 & 0.240 & 0.427 \\
\hline Central region & 0.265 & 0.441 & 0.274 & 0.446 & 0.248 & 0.432 \\
\hline East region & 0.470 & 0.499 & 0.448 & 0.497 & 0.512 & 0.500 \\
\hline Observations & 48,856 & & 32,598 & & 16,258 & \\
\hline \multicolumn{7}{|c|}{ Panel C: 2007-2013 } \\
\hline Sectors: public sector & 0.661 & 0.473 & & & & \\
\hline Male & 0.485 & 0.500 & 0.476 & 0.499 & 0.502 & 0.500 \\
\hline Schooling year & 12 & 3 & 12 & 3 & 12 & 3 \\
\hline Experience year & 29 & 13 & 29 & 14 & 29 & 10 \\
\hline Occupations: blue-color workers & 0.127 & 0.333 & 0.098 & 0.297 & 0.184 & 0.387 \\
\hline Industries: manufacturing & 0.129 & 0.335 & 0.088 & 0.284 & 0.208 & 0.406 \\
\hline \multicolumn{7}{|l|}{ Regions } \\
\hline West region & 0.231 & 0.422 & 0.240 & 0.427 & 0.214 & 0.410 \\
\hline Central region & 0.214 & 0.410 & 0.214 & 0.410 & 0.214 & 0.410 \\
\hline East region & 0.555 & 0.497 & 0.546 & 0.498 & 0.572 & 0.495 \\
\hline Observations & 22,385 & & 14,807 & & 7,578 & \\
\hline
\end{tabular}

Source: Calculated using CHIPs 1995, CHIPs 2002, CHIPs 2007 and CHIPs 2013. 
For example, the average schooling year is more for the public sector (11 years in the 1993-1995 period, 12 years in the 1998-2002 period) than for the private sector (9 years in the 1993-1995 period, 11 years in the 1998-2002 period). However, the average schooling year is similar for the public and private sectors in the 2007-2013 period. Moreover, the proportions of manufacturing industry workers are more for the private sector (51.6\% in the $1993-1995$ period, $32.8 \%$ in the $1998-2002$ period, $20.8 \%$ in the $2007-2013$ period) than for the public sector (37.2\% in the $1993-1995$ period, $21.6 \%$ in the $1998-2002$ period, $8.8 \%$ in the $2007-2013$ period).

\subsection{Descriptive Statistics of Wage by Sectors and Periods}

Table 2 shows the descriptive statistics of wage by sectors and periods. First, the mean values of the logarithm of wage rate are higher for the public sector (6.111 in the 1993-1995 period, 6.571 in the 1998-2002 period, 7.127 in the 2007-2013 period) than for the private sector (5.815 in the 1993-1995 period, 6.323 in the 19982002 period, 7.038 in the $2007-2013$ period).

Second, for the low and middle wage level groups (25 percentile wage group, 50 percentile wage group, 75 percentile wage group), the wage levels in the public sector are higher compared to the private sector (in the three periods).

Third, the minimum wage levels are lower for the public sector (1.609 in the 1993-1995 period, 2.575 in the 1998-2002 period) than for the private sector (1.872 in the 1993-1995 period, 2.703 in the 1998-2002 period). However, it is higher for the public sector (7.127) than for the private sector (7.038) in the 2007-2013 period.

Fourth, the maximum wage levels are higher for the public sector in the 1993-1995 and the 1998-2002 periods; however, they are higher for the private sector (11.521) than for the public sector (10.199) in the 20072013 period.

Fifth, from 1993 to 2002, the standard deviation values are greater for the private sector (0.714 in the 19931995 period, 0.691 in the $1998-2002$ period) than for the public sector $(0.575$ in the 1993-1995 period, 0.613 in the 1998-2002 period). However, it is greater for the public sector (1.101) than for the private sector $(0.880)$ in the 2008-2013 period. Although the wage gaps within sectors exhibit growth in both the public and private sectors from 1993 to 2013, it is greatest for the public sector in the 2007-2013 period.

\subsection{Maximum MW Levels and the Kernel Density Estimates of Wage Distribution by Sectors and Periods}

Considering the effect of MW on wage distribution, it is pointed out in the previous studies that there exists a spike effect for the group with wage below or around the MW level. Does the spike effect exist in urban China? Wage distribution using kernel density estimates are calculated for the three periods. These results are shown in Figure 1.

Table 2. Descriptive statistics of wage by sectors and periods.

\begin{tabular}{|c|c|c|c|c|c|c|}
\hline & \multicolumn{2}{|c|}{ Panel A: 1993-1995 } & \multicolumn{2}{|c|}{ Panel B: 1998-2002 } & \multicolumn{2}{|c|}{ Panel B: 2007-2013 } \\
\hline & Private & Public & Private & Public & Private & Public \\
\hline Maximum & 9.050 & 11.157 & 9.900 & 10.441 & 11.521 & 10.199 \\
\hline Minimum & 1.872 & 1.609 & 2.703 & 2.575 & 1.904 & 1.680 \\
\hline Mean & 5.815 & 6.111 & 6.323 & 6.571 & 7.038 & 7.127 \\
\hline S.D. & 0.714 & 0.575 & 0.691 & 0.613 & 0.880 & 1.101 \\
\hline p25 & 5.454 & 5.831 & 5.901 & 6.239 & 6.558 & 6.805 \\
\hline p50 (Median) & 5.859 & 6.147 & 6.288 & 6.605 & 7.098 & 7.343 \\
\hline p75 & 6.194 & 6.443 & 6.725 & 6.949 & 7.609 & 7.763 \\
\hline p25/p50 & 0.931 & 0.949 & 0.939 & 0.945 & 0.924 & 0.927 \\
\hline p75/p50 & 1.057 & 1.048 & 1.069 & 1.052 & 1.072 & 1.057 \\
\hline
\end{tabular}

Source: Calculated using CHIPs 1995, CHIPs 2002, CHIPs 2007 and CHIPs 2013. 
Panel A: 1994-1995 (MW beginning period)

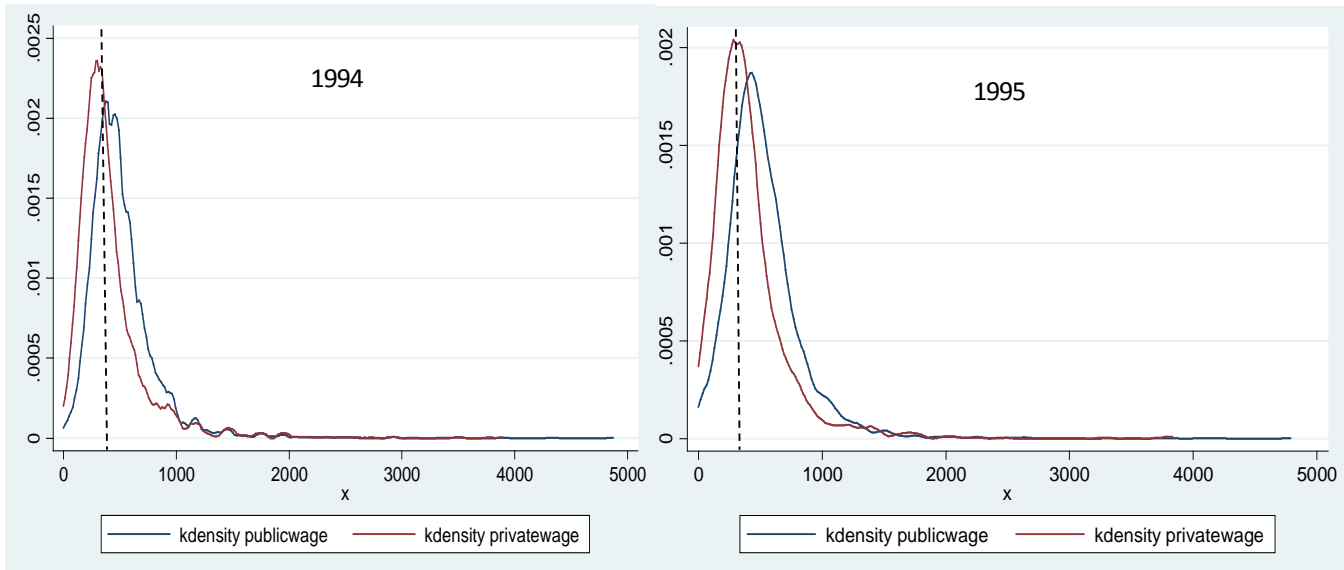

Panel B: 1998-2002 ( MW performed period)
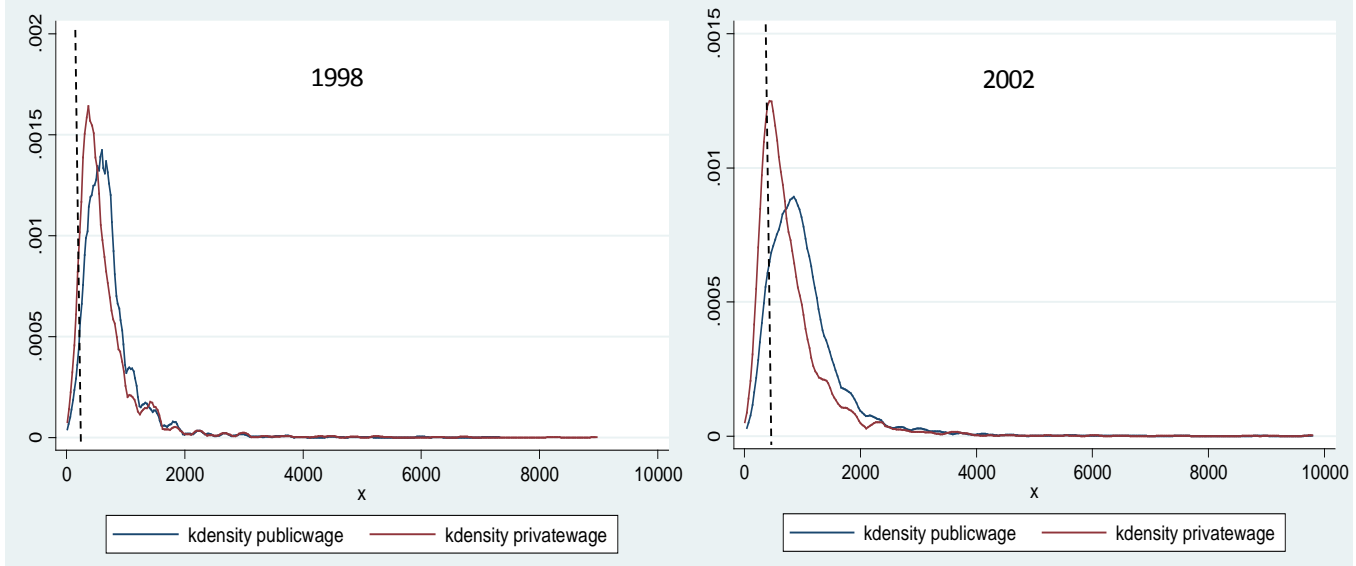

Panel C: 2007-2013( MW enforcement period)
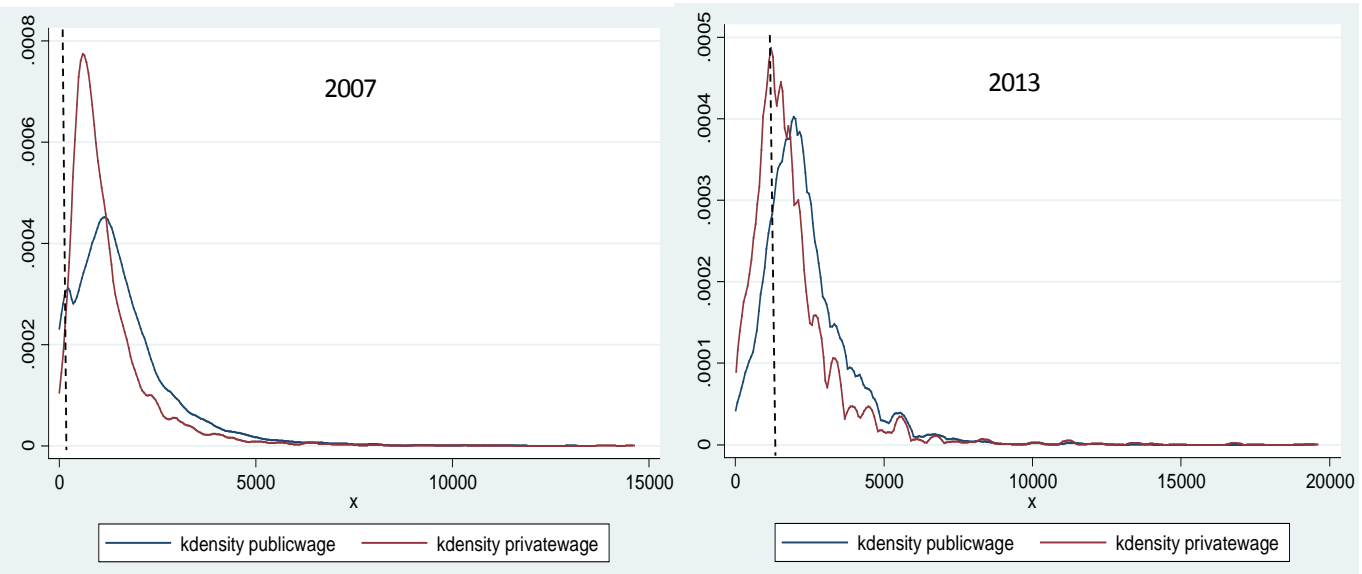

Note: The dotted line shows the maximum values of the MW levels.

Source: Calculated using CHIsP1995,CHIPs2002,CHIPs2007,CHIPs2013.

Figure 1. Maximum MW levels and the kernel density estimates of wage distribution among the public sector and the private sector in urban China. 
There seems to be a small spike shapes in the wage distribution in 1994 for public sector and private sector, in 2007 for public sector, and in 2013 for the private sector. The spike-shaped wage distribution showed that the proportions of groups around the maximum values of the MW level, particularly for the group with the wage just a little more than the maximum values of the MW level are greater-it indicated that the MW increased the wage levels around the MW before the MW enforcement. As it is described from the above, the MW was first promulgated as a law_Enterprise's Minimum Wage Regulations_in 1993, and it was enforced since 2004 in China, therefore these estimated results indicated that there exist the spike effects in urban China for the MW beginning period (1993-1995), and the MW enforcement period (2007-2013).

\section{Econometric Analysis Results}

\subsection{Results of MW Effects on Average Wage}

Table 3 shows the results of wage function using OLS model for the 1993-1995 period, the 1998-2002 period and the 2007-2013 period. We observe the effect of MW on average wage through the estimated coefficient of the MW logarithmic value.

First (Estimation 1), the estimated coefficients of MW logarithmic values are the greatest for the 1998-2002 period and smallest for the 1993-1995 period. Comparing the impact of the MW system at the beginning to the present times, the effects of MW level on the average wage level is becoming greater.

In additions, holding the other factors consistent, the average wage level is higher for the public sector than for the private sector (17.4\% higher in the 1993-1995 period, 16.2\% higher in the 1998-2002 period, 9.3\% higher in the 2007-2013 period). Wage gaps between the public and private sectors exist in urban China even though the human capital of workers is consistent in these two sectors from 1993 to 2013.

Second (Estimation 2 and Estimation 3), if the sample is divided between the public and private sectors, the effects of the MW are all positively significant in the three periods, and the coefficients of MW logarithmic values are greater for the private sector than for the public sector in the three periods. Results showed that although the MW effect exists in both public sector and private sector, it is greater for the private sector than for the public sector.

Third (Estimation 4), results of Estimation 2 and Estimation 3 might be caused by the human capital differential and distribution proportion differential in terms of occupation, industry, and regions between these two sectors. Therefore, Estimation 4 is employed to control these influences. The estimated coefficients of interaction items of $\ln M W$ and $P u b$ are all negatively significant in the three periods $(-0.330$ in the 1993-1995 period, -0.046 in the 1998-2002 period, -0.375 in the 2007-2013 period). It indicated that, when holding the other factors consistent, the effect of MW level on average wage is greater for the private sector than for public sector. These results are consistent with the results in Estimation 2 and Estimation 3.

\subsection{Results of MW Effects on Wage Distribution in the Public and Private Sectors}

Figure 2 shows the estimated coefficients of MW logarithmic values based on the Quantile Regression (QR) model using total samples for the three periods. We observe the effect of MW on wage distribution through the estimated coefficient of the MW logarithmic value by wage percentiles.

First, the estimated coefficients of MW logarithmic values for the low-wage group $\left(5^{\text {th }}, 10^{\text {th }}, 20^{\text {th }}, 30^{\text {th }}\right.$ percentile wage groups) are greatest in the 2007-2013 period; they are smallest in the 1993-1995 period. It is indicated that after the government has enforced the implementation of the MW policy since 2004, the effect of MW on low-wage group has become greater.

Second, the estimated coefficients of MW logarithmic values are greater for the low-wage group than for the middle- and high-wage group in the 2007-2013 period, whereas they are greater for the high-wage group than that for the middle-wage group in the 1993-1995 and 1998-2002 periods. It indicated that the spillover effects are relatively greater for the high-wage group than for the middle-wage groups from 1993 to 2002; however, the same is smaller in the 2007-2013 period.

Do the differences of MW effect between the public sector and the private sector exist? To answer the question, two types of estimations are employed; they are shown in Figure 3 and Table 4.

First, using the subsamples, the total samples are divided into two subsamples - the public sector group and the private sector group. Estimations by the two sectors are employed and the results are summarized as follows: 
Table 3. Results of MW effects on average wage.

\begin{tabular}{|c|c|c|c|c|c|c|c|c|}
\hline \multicolumn{9}{|c|}{ Panel A: 1993-1995 } \\
\hline & \multicolumn{2}{|c|}{ (1) Public + private } & \multicolumn{2}{|c|}{ (2) Public } & \multicolumn{2}{|c|}{ (3) Private } & \multicolumn{2}{|c|}{ (4) Public + private } \\
\hline & coef. & t-val. & coef. & t-val. & coef. & t-val. & coef. & t-val. \\
\hline $\ln M W$ & $0.759^{* * *}$ & 28.90 & $0.685^{* * *}$ & 24.35 & $0.985^{* * *}$ & 14.45 & $1.011^{* * *}$ & 27.33 \\
\hline \multicolumn{9}{|c|}{ Sector (private sector) } \\
\hline Public sector & $0.174^{* * *}$ & 13.73 & & & & & $2.008^{* * *}$ & 10.53 \\
\hline $\operatorname{lnMW} *$ public & & & & & & & $-0.330^{* * *}$ & -9.64 \\
\hline Male & $0.155^{* * *}$ & 15.86 & $0.136^{* * *}$ & 13.14 & $0.214^{* * *}$ & 8.22 & $0.152^{* * *}$ & 15.62 \\
\hline Education & $0.041^{* * *}$ & 21.16 & $0.040^{* * *}$ & 19.66 & $0.046^{* * *}$ & 8.05 & $0.042^{* * *}$ & 21.49 \\
\hline Exp. & $0.059^{* * * *}$ & 24.43 & $0.063^{* * *}$ & 24.19 & $0.051^{* * *}$ & 8.28 & $0.060^{* * *}$ & 24.80 \\
\hline Exp.-sq. & $-0.001^{* * *}$ & -18.56 & $-0.001^{* * *}$ & -18.19 & $-0.001^{* * *}$ & -6.57 & $-0.001^{* * *}$ & -18.78 \\
\hline \multicolumn{9}{|c|}{ Occupations (no-blue-color workers) } \\
\hline Blue-color workers & $-0.133^{* * *}$ & -11.60 & $-0.139^{* * *}$ & -11.19 & $-0.086^{* * *}$ & -3.11 & $-0.128^{* * *}$ & -11.22 \\
\hline \multicolumn{9}{|c|}{ Industries (no-manufacturing) } \\
\hline Manufacturing & -0.013 & -1.27 & $-0.022^{*}$ & -1.96 & 0.013 & 0.48 & -0.015 & -1.43 \\
\hline \multicolumn{9}{|l|}{ Regions (east) } \\
\hline West & $-0.078^{* * *}$ & -5.46 & $-0.066^{* * *}$ & -4.39 & $-0.154^{* * *}$ & -3.98 & $-0.083^{* * *}$ & -5.84 \\
\hline Central & $0.081^{* * *}$ & 5.08 & $0.079^{* * *}$ & 4.80 & 0.047 & 1.03 & $0.073^{* * *}$ & 4.60 \\
\hline Year dummy & Yes & & Yes & & Yes & & Yes & \\
\hline Cons. & $0.573^{* * *}$ & 3.38 & $1.099^{* * *}$ & 6.09 & -0.610 & -1.39 & $-0.862^{* * *}$ & -3.83 \\
\hline Obs. & 13,410 & & 10,818 & & 2,592 & & 13,410 & \\
\hline Adj.R-sq. & 0.322 & & 0.313 & & 0.332 & & 0.326 & \\
\hline
\end{tabular}

\section{Panel B: 1998-2002}

\begin{tabular}{|c|c|c|c|c|c|c|c|c|}
\hline & \multicolumn{2}{|c|}{ (1) Public + private } & \multicolumn{2}{|c|}{ (2) Public } & \multicolumn{2}{|c|}{ (3) Private } & \multicolumn{2}{|c|}{ (4) Public + private } \\
\hline & coef. & t-val. & coef. & t-val. & coef. & t-val. & coef. & t-val. \\
\hline $\operatorname{lnMW}$ & $1.048^{* * *}$ & 52.36 & $0.922^{* * *}$ & 40.99 & $1.298^{* * *}$ & 32.08 & $1.078^{* * *}$ & 43.25 \\
\hline \multicolumn{9}{|c|}{ Sector (private sector) } \\
\hline Public sector & $0.162^{* * *}$ & 27.80 & & & & & $0.424^{* * *}$ & 3.36 \\
\hline $\operatorname{lnMW} *$ public & & & & & & & $-0.046^{* *}$ & -2.07 \\
\hline Male & $0.189^{* * *}$ & 35.26 & $0.146^{* * *}$ & 23.51 & $0.275^{* * *}$ & 27.17 & $0.189^{* * *}$ & 35.26 \\
\hline Education & $0.063^{* * *}$ & 55.74 & $0.063^{* * *}$ & 46.90 & $0.060^{* * *}$ & 27.84 & $0.063^{* * *}$ & 55.70 \\
\hline Exp. & $0.039^{* * *}$ & 26.30 & $0.045^{* * *}$ & 26.32 & $0.025^{* * *}$ & 8.88 & $0.039^{* * *}$ & 26.32 \\
\hline Exp.-sq. & $0.000^{* * *}$ & -17.44 & $-0.001^{* * *}$ & -17.62 & $0.000^{* * *}$ & -5.62 & $0.000^{* * *}$ & -17.46 \\
\hline
\end{tabular}




\section{Continued}

Occupations (no-blue-color workers)

\begin{tabular}{|c|c|c|c|c|c|c|c|c|}
\hline Blue-color workers & $-0.062^{* * *}$ & -9.27 & $-0.065^{* * *}$ & -8.28 & $-0.073^{* * *}$ & -5.92 & $-0.062^{* * *}$ & -9.27 \\
\hline \multicolumn{9}{|c|}{ Industries (no-manufacturing) } \\
\hline Manufacturing & $-0.071^{* * *}$ & -10.87 & $-0.133^{* * *}$ & -17.20 & $0.031^{* * *}$ & 2.65 & $-0.071^{* * *}$ & -10.88 \\
\hline \multicolumn{9}{|l|}{ Regions (East) } \\
\hline West & $-0.023^{* * *}$ & -2.80 & $-0.046^{* * *}$ & -5.00 & 0.023 & 1.36 & $-0.023^{* * *}$ & -2.77 \\
\hline Central & $0.130^{* * *}$ & 14.16 & $0.113^{* * *}$ & 11.13 & $0.173^{* * *}$ & 9.10 & $0.130^{* * *}$ & 14.20 \\
\hline Year dummy & Yes & & Yes & & Yes & & Yes & \\
\hline Cons. & -0.967 & -8.48 & $-0.198^{* * *}$ & -1.54 & $-2.098^{* * *}$ & -9.12 & $-1.143^{* * *}$ & -8.04 \\
\hline Obs. & 46,740 & & 31,502 & & 15,238 & & 46,740 & \\
\hline Adj.R-sq. & 0.259 & & 0.259 & & 0.218 & & 0.259 & \\
\hline
\end{tabular}

Panel C: 2007-2013

\begin{tabular}{|c|c|c|c|c|c|c|c|c|}
\hline & \multicolumn{2}{|c|}{ (1) Public + private } & \multicolumn{2}{|c|}{ (2) Public } & \multicolumn{2}{|c|}{ (3) Private } & \multicolumn{2}{|c|}{ (4) Public + private } \\
\hline & coef. & t-val. & coef. & t-val. & coef. & t-val. & coef. & t-val. \\
\hline lnMW & $0.855^{* * *}$ & 52.50 & $0.719^{* * *}$ & 32.68 & $1.020^{* * *}$ & 42.42 & $1.055^{* * *}$ & 43.29 \\
\hline
\end{tabular}

Sector (private sector)

\begin{tabular}{|c|c|c|c|c|c|c|c|c|}
\hline Public sector & $0.093^{* * *}$ & 8.10 & & & & & $2.269^{* * *}$ & 11.47 \\
\hline lnMW*public & & & & & & & $-0.339^{* * *}$ & -11.02 \\
\hline Male & $0.365^{* * *}$ & 33.42 & $0.400^{* * *}$ & 25.29 & $0.315^{* * *}$ & 21.44 & $0.363^{* * *}$ & 33.37 \\
\hline Education & $0.105^{* * *}$ & 44.40 & $0.131^{* * *}$ & 37.06 & $0.082^{* * *}$ & 26.38 & $0.106^{* * *}$ & 45.19 \\
\hline Exp. & $0.066^{* * *}$ & 26.80 & $0.092^{* * *}$ & 24.96 & $0.040^{* * *}$ & 12.14 & $0.067^{* * *}$ & 27.04 \\
\hline Exp.-sq. & $-0.001^{* * *}$ & -24.89 & $-0.001^{* * *}$ & -23.00 & $-0.001^{* * *}$ & -11.35 & $-0.001^{* * *}$ & -25.04 \\
\hline \multicolumn{9}{|l|}{ ccupations (others) } \\
\hline Blue-color workers & $0.027^{*}$ & 1.73 & $0.166^{* * *}$ & 6.85 & $-0.068^{* * *}$ & -3.33 & $0.029^{*}$ & 1.83 \\
\hline \multicolumn{9}{|c|}{ Industries (others) } \\
\hline Manufacturing & $0.083^{* * *}$ & 5.21 & $0.066^{* * *}$ & 2.60 & $0.112^{* * *}$ & 5.61 & $0.078^{* * *}$ & 4.92 \\
\hline \multicolumn{9}{|l|}{ Regions (East) } \\
\hline West & $0.026^{* *}$ & 1.98 & 0.021 & 1.11 & 0.012 & 0.63 & $0.026^{* *}$ & 2.00 \\
\hline Central & $-0.046^{* * *}$ & -3.29 & $-0.079^{* * *}$ & -3.92 & -0.027 & -1.44 & $-0.042^{* * *}$ & -3.02 \\
\hline Year dummy & Yes & & Yes & & Yes & & Yes & \\
\hline Cons. & $-0.865^{* * *}$ & -7.01 & $-0.640^{* * *}$ & -3.87 & $-1.279^{* * *}$ & -7.00 & $-2.196^{* * *}$ & -12.73 \\
\hline Obs. & 23,310 & & 12,027 & & 11,283 & & 24,428 & \\
\hline Adj.R-sq. & 0.251 & & 0.278 & & 0.231 & & 0.255 & \\
\hline
\end{tabular}

Note: ${ }^{*},{ }^{* *},{ }^{* * *}$ : statistically significant in 10\%, 5\%, 1\% levels. Source: Calculated using CHIPs 1995, CHIPs 2002 , CHIPs 2007 and CHIPs 2013. 
Table 4. Results of the differences of MW effect on wage distribution between the public and private sectors.

\begin{tabular}{|c|c|c|c|c|c|}
\hline & $\ln M W$ & Public & $\operatorname{lnMW}$ *public & Constants & $\mathrm{R}^{2}$ \\
\hline \multicolumn{6}{|c|}{ Panel A: 1993-1995 } \\
\hline $1^{\mathrm{st}}$ & $1.213^{* * *}$ & 3.200 & -0.488 & $-5.638^{* *}$ & 0.172 \\
\hline $5^{\text {th }}$ & $1.021^{* * *}$ & $3.034^{* * *}$ & $-0.483^{* * *}$ & $-3.113^{* * *}$ & 0.176 \\
\hline $10^{\text {th }}$ & $0.925^{* * *}$ & $2.368^{* * *}$ & $-0.378^{* * *}$ & $-1.752^{* * *}$ & 0.186 \\
\hline $20^{\text {th }}$ & $0.896^{* * *}$ & $2.301^{* * *}$ & $-0.378^{* * *}$ & $-0.934^{* * *}$ & 0.190 \\
\hline $30^{\text {th }}$ & $0.879^{* * *}$ & $1.954^{* * *}$ & $-0.317^{* * *}$ & $-0.414^{*}$ & 0.191 \\
\hline $40^{\text {th }}$ & $0.898^{* * *}$ & $1.939^{* * *}$ & $-0.316^{* * *}$ & -0.240 & 0.194 \\
\hline $50^{\text {th }}$ & $0.882^{* * *}$ & $1.613^{* * *}$ & $-0.260^{* * *}$ & 0.065 & 0.200 \\
\hline $60^{\text {th }}$ & $0.932^{* * *}$ & $1.703^{* * *}$ & $-0.277^{* * *}$ & -0.027 & 0.207 \\
\hline $70^{\text {th }}$ & $0.987^{* * *}$ & $1.795^{* * *}$ & $-0.295^{* * *}$ & -0.037 & 0.215 \\
\hline $80^{\text {th }}$ & $1.051^{* * *}$ & $1.926^{* * *}$ & $-0.320^{* * *}$ & -0.136 & 0.228 \\
\hline $90^{\text {th }}$ & $1.176^{* * *}$ & $2.046^{* * *}$ & $-0.350^{* * *}$ & $-0.499^{*}$ & 0.245 \\
\hline \multicolumn{6}{|c|}{ Panel B: 1998-2002 } \\
\hline $1^{\mathrm{st}}$ & $1.034^{* * *}$ & -0.544 & 0.141 & $-3.936^{* * *}$ & 0.075 \\
\hline $5^{\text {th }}$ & $0.953^{* * *}$ & -0.075 & 0.053 & $-2.206^{* * *}$ & 0.121 \\
\hline $10^{\text {th }}$ & $0.961^{* * *}$ & 0.032 & 0.035 & $-1.616^{* * *}$ & 0.130 \\
\hline $20^{\text {th }}$ & $0.918^{* * *}$ & -0.068 & 0.054 & $-0.930^{* * *}$ & 0.151 \\
\hline $30^{\text {th }}$ & $0.926^{* * *}$ & 0.061 & 0.029 & $-0.634^{* * *}$ & 0.161 \\
\hline $40^{\text {th }}$ & $0.938^{* * *}$ & $0.229^{*}$ & -0.004 & $-0.467^{* * *}$ & 0.164 \\
\hline $50^{\text {th }}$ & $0.944^{* * *}$ & $0.500^{* * *}$ & $-0.055^{* *}$ & $-0.315^{* *}$ & 0.163 \\
\hline $60^{\text {th }}$ & $0.939^{* * *}$ & $0.426^{* * *}$ & $-0.047^{* *}$ & -0.098 & 0.161 \\
\hline $70^{\text {th }}$ & $1.002^{* * *}$ & $0.520^{* * *}$ & $-0.068^{* * *}$ & -0.245 & 0.160 \\
\hline $80^{\text {th }}$ & $1.111^{* * *}$ & $0.722^{* * *}$ & $-0.111^{* * *}$ & $-0.660^{* * *}$ & 0.163 \\
\hline $90^{\text {th }}$ & $1.209^{* * *}$ & $1.021^{* * *}$ & $-0.171^{* * *}$ & $-0.816^{* * *}$ & 0.164 \\
\hline \multicolumn{6}{|c|}{ Panel C: 2007-2013 } \\
\hline $1^{\text {st }}$ & $1.063^{* * *}$ & 1.852 & -0.331 & $-7.502^{* * *}$ & 0.166 \\
\hline $5^{\text {th }}$ & $1.121^{* * *}$ & $0.762^{*}$ & $-0.126^{*}$ & $-6.342^{* * *}$ & 0.137 \\
\hline $10^{\text {th }}$ & $1.152^{* * *}$ & $1.391^{* * *}$ & -0.228 & $-4.803^{* * *}$ & 0.138 \\
\hline $20^{\text {th }}$ & $1.128^{* * *}$ & $2.167^{* * *}$ & -0.316 & $-3.341^{* * *}$ & 0.155 \\
\hline $30^{\text {th }}$ & $1.098^{* * *}$ & $2.256^{* * *}$ & -0.327 & $-2.635^{* * *}$ & 0.165 \\
\hline $40^{\text {th }}$ & $1.093^{* * *}$ & $2.661^{* * *}$ & -0.387 & $-2.223^{* * *}$ & 0.167 \\
\hline $50^{\text {th }}$ & $1.043^{* * *}$ & $2.746^{* * *}$ & -0.400 & $-1.667^{* * *}$ & 0.170 \\
\hline $60^{\text {th }}$ & $1.012^{* * *}$ & $2.693^{* * *}$ & -0.392 & $-1.248^{* * *}$ & 0.173 \\
\hline $70^{\text {th }}$ & $0.995^{* * *}$ & $2.787^{* * *}$ & -0.409 & $-0.909^{* * *}$ & 0.175 \\
\hline $80^{\text {th }}$ & $0.943^{* * *}$ & $2.386^{* * *}$ & -0.350 & $-0.275^{* * *}$ & 0.177 \\
\hline $90^{\text {th }}$ & $0.922^{* * *}$ & $2.231^{* * *}$ & -0.331 & $0.234^{* * *}$ & 0.177 \\
\hline
\end{tabular}

Note: 1) The other variables-male, education, experience year, occupations, indutries, region dummy, year dummy are also extimated in these models. 2) ${ }^{*},{ }^{* *},{ }^{* * *}$ : statistically significant in 10\%, 5\%, 1\% levels. Source: Calculated using CHIPs 1995, CHIPs 2002, CHIPs 2007 and CHIPs 2013. 


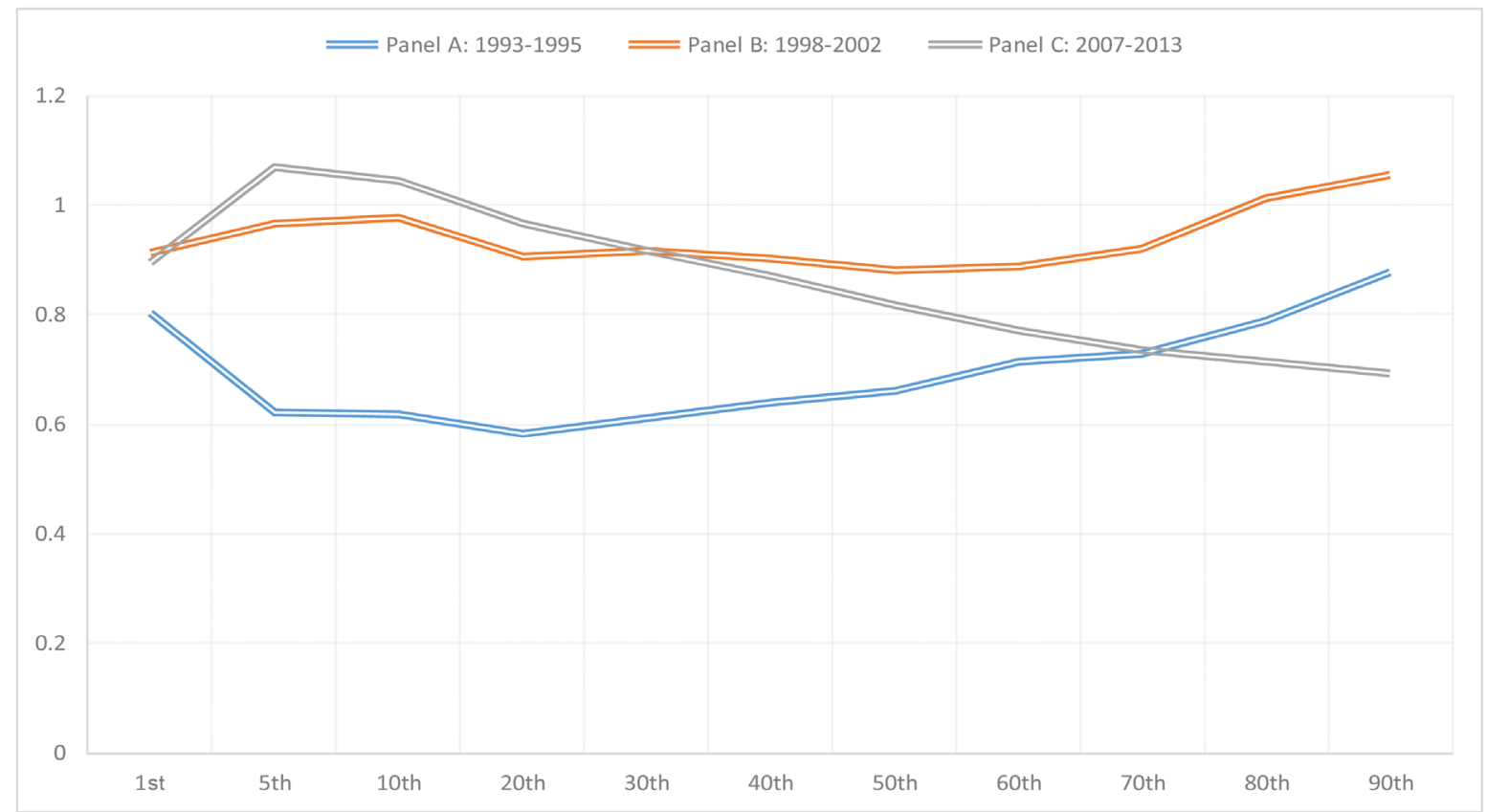

Note 1.The other varibles - male, education, experience year, occupation, industry, public sector, region dummy, Year dummy are also extimated.

2. coefficients of $\ln M W$ based on quantile regression model are shown in Figure2. coefficients of $\operatorname{lnMW}$ are all statistically significant at 1 5\% level.

Source: Calculated using CHIPs1995,CHIPs2002, CHIPs2007, CHIPs2013.

Figure 2. Results of MW effects on wage distribution by periods.

1) The estimated coefficients of the MW logarithmic values indicated that except the lowest-wage group $\left(1^{\text {st }}\right.$ percentile) in the 1998-2002 period, the estimated coefficients of MW logarithmic values are greater for all in the private sector than for the public sector in the three periods.

2) The differences of the estimated coefficients of MW logarithmic values between the public and private sector for the low-wage group are greatest in the 2007-2013 period.

These results showed that although the effects of MW on wage distribution are greater for the private sector than for the public sector in the three periods, the effect of MW on the low-wage group has increased in the 2007-2013 period.

Second, considering the human capital differentials between the public and private sectors, estimations holding the other factors-including the human capitals consistent-are employed, and the results are shown in Table 5. Comparing the MW effect differences between the public sector and private sector, the estimated coefficients of interaction items of $\ln M W$ and $P u b$ are utilized. In the 1993-1995 and the 2007-2013 periods, except the low-wage group $\left(1^{\text {st }}, 5^{\text {th }}\right.$ wage percentiles), the coefficient of the interaction items are all negatively significant in the overall wage distribution. It indicated that the MW effects on most of the wage distribution are greater for the private sector than for the public sector in the MW beginning period and the MW enforcement period.

\subsection{Results of MW Effects on the Wage Gap between the Public and Private Sectors}

Results of the MW effects on the wage gap between the public and private sectors are shown in Table 5.

First, overall, the influences of both unexplained differential and explained differential affect the wage gaps between the public and private sectors in the three periods. Moreover, the influences of unexplained differential differ by the periods. For example, the influences of unexplained differential are greater than the explained differential in both the 1993-1995 period and the 1998-2002 period; however, the influences of explained differential are greater than the unexplained differential in the 2007-2013 period. Concretely, the percentages of 

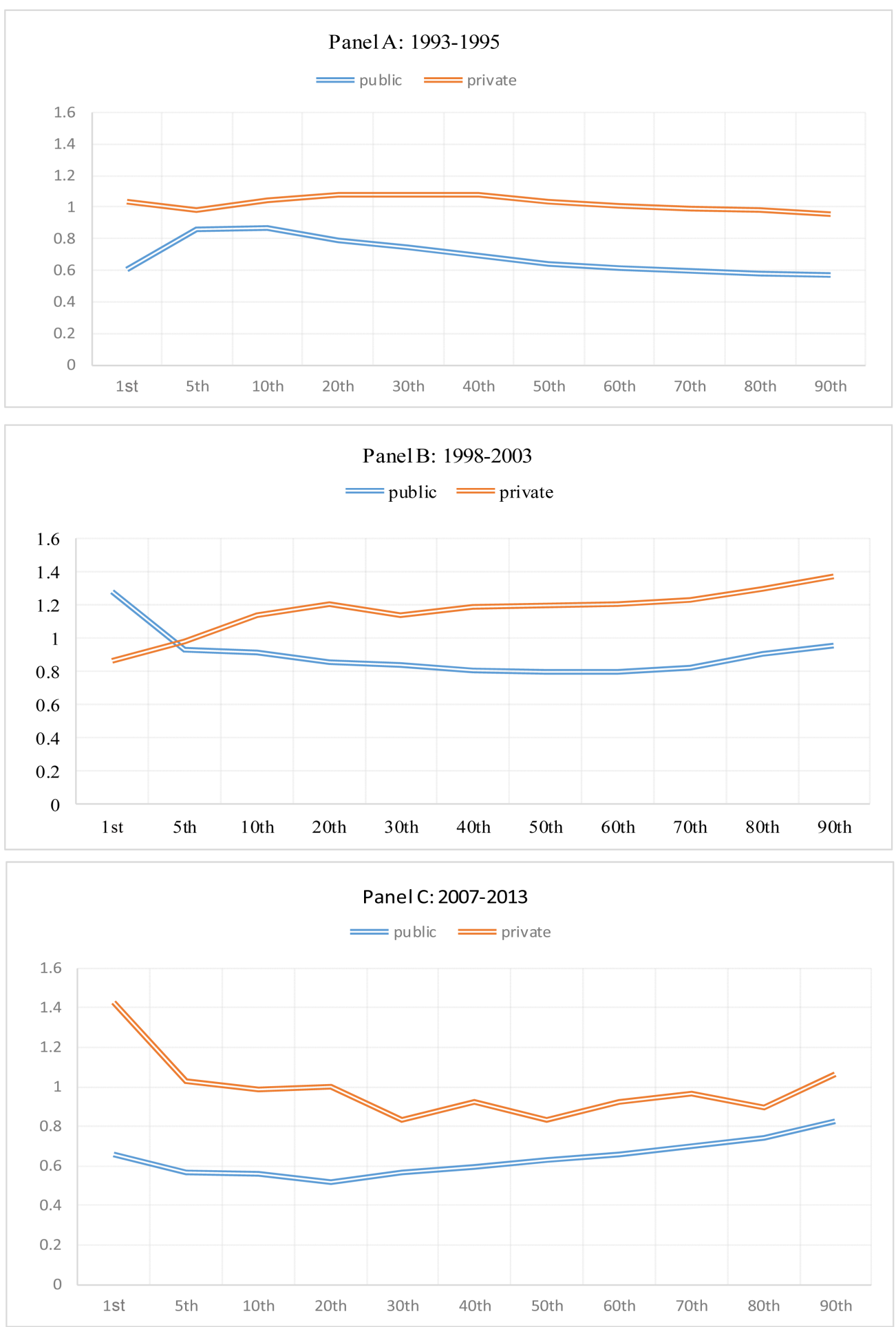

Note 1 .The other varibles - male, education, experience year, occupation, industry, public sector, region dummy, Year dummy are also extimated.

2. coefficients of lnMW based on quantile regression model are shown in Figure2. coefficients of $\operatorname{lnMW}$ are all statistically significant at $1 \sim 5 \%$ level.

Source: Calculated using CHIPs1995,CHIPs2002, CHIPs2007, CHIPs2013.

Figure 3. Results of MW effects on wage distribution by the public and private sectors. 
Table 5. Decomposition results of the MW effects on wage gaps between the public and private sectors.

\begin{tabular}{|c|c|c|c|c|}
\hline & \multicolumn{2}{|c|}{ Explained differentials } & \multicolumn{2}{|c|}{ Unexpained differentials } \\
\hline & Actural value & Percentage (\%) & Actural value & Percentage (\%) \\
\hline \multicolumn{5}{|c|}{ Panel A: 1993-1995 } \\
\hline Total & 0.047 & $22.1 \%$ & 0.167 & $77.9 \%$ \\
\hline
\end{tabular}

Decomposition category:

\begin{tabular}{|c|c|c|c|c|}
\hline $\ln M W$ & -0.084 & $-39.1 \%$ & -1.685 & $-787.2 \%$ \\
\hline Education & 0.068 & $31.9 \%$ & -0.045 & $-21.1 \%$ \\
\hline Experience year & 0.014 & $6.7 \%$ & 0.225 & $105.1 \%$ \\
\hline Male & 0.018 & $8.4 \%$ & -0.033 & $-15.3 \%$ \\
\hline Occupation & 0.024 & $11.1 \%$ & -0.026 & $-12.1 \%$ \\
\hline Industry & 0.004 & $1.8 \%$ & -0.018 & $-8.6 \%$ \\
\hline Region & 0.003 & $1.3 \%$ & 0.019 & $8.9 \%$ \\
\hline Constant & 0.000 & $0.0 \%$ & 1.730 & $808.2 \%$ \\
\hline \multicolumn{5}{|c|}{ Panel B: 1998-2002 } \\
\hline Total & 0.094 & $37.8 \%$ & 0.155 & $62.2 \%$ \\
\hline \multicolumn{5}{|c|}{ Decomposition category: } \\
\hline $\operatorname{lnMW}$ & -0.031 & $-12.6 \%$ & 0.153 & $61.5 \%$ \\
\hline Education & 0.094 & $37.8 \%$ & 0.021 & $8.4 \%$ \\
\hline Experience year & 0.004 & $1.6 \%$ & 0.322 & $129.3 \%$ \\
\hline Male & 0.009 & $3.7 \%$ & -0.074 & $-29.9 \%$ \\
\hline Occupation & 0.002 & $0.8 \%$ & 0.002 & $0.9 \%$ \\
\hline Industry & 0.016 & $6.5 \%$ & -0.037 & $-14.7 \%$ \\
\hline Region & 0.000 & $0.0 \%$ & 0.035 & $14.2 \%$ \\
\hline Constant & 0.000 & $0.0 \%$ & -0.267 & $-107.5 \%$ \\
\hline \multicolumn{5}{|c|}{ Panel C: 2007-2013 } \\
\hline Total & 0.151 & $85.4 \%$ & 0.026 & $14.6 \%$ \\
\hline \multicolumn{5}{|c|}{ Decomposition category: } \\
\hline $\ln M W$ & -0.102 & $-57.4 \%$ & -1.955 & $-1102.4 \%$ \\
\hline Education & 0.223 & $125.7 \%$ & 0.560 & $316.0 \%$ \\
\hline Experience year & 0.018 & $10.2 \%$ & 0.710 & $400.6 \%$ \\
\hline Male & 0.023 & $13.1 \%$ & 0.043 & $24.5 \%$ \\
\hline Occupation & -0.008 & $-4.3 \%$ & 0.048 & $26.9 \%$ \\
\hline Industry & -0.005 & $-2.9 \%$ & -0.009 & $-5.3 \%$ \\
\hline Region & 0.002 & $1.1 \%$ & -0.010 & $-5.8 \%$ \\
\hline Constant & 0.000 & $0.0 \%$ & 0.639 & $360.2 \%$ \\
\hline
\end{tabular}

Source: Calculated using CHIPs 1995, CHIPs 2002, CHIPs 2007 and CHIPs 2013. 
unexplained differential are $77.9 \%$ in the $1993-1995$ period and $61.5 \%$ in the $1998-2002$ period, whereas the percentages are only $14.6 \%$ in the $2007-2013$ period. It indicated that along with the transition of the economy systems, the differentials caused by wage determine systems decreased; the influences of explained differentials, including the human capital differences, increased.

Second, considering the influence of the MW on wage gap, (1) the estimated values of the MW as a component of explained differential are all negative values in the three period (-39.1\% in the $1993-1995$ period, $-12.6 \%$ in the $1998-2002$ period, $-57.4 \%$ in the $2007-2013$ period). It indicates that the differential of distribution proportions in the regions with different MW levels between the public sector and the private sector contributes to reduce the wage gap.

It can be explained that if the distribution proportions in the high MW level region are greater for the private sector (in the case when most private firms, individual firms, and foreign investment firms are concentrating in the east region where the MW levels are higher than other regions), the wage gaps between these two sectors might be reduced by the MW implementation. Based on the CHIPs data, the proportion of workers with wages lower than the MW are greater for the private sector (7.2\% in the 19931995 period, $12.4 \%$ in the $1998-2002$ period, $16.3 \%$ in the $2007-2013$ period) than for the public sector (3.0\% in the 19931995 period, $5.2 \%$ in the 1998 2002 period, $11.4 \%$ in the 20072013 period).

(2) The estimated values of the MW as a component of unexplained differentials are negative in the 19931995 (-782.2\%) and 2007-2013 periods (-1102.4\%). However, the value was positive (61.5\%) in the 19982002 period. It indicates that the MW effects on wage are greater for the private sector than for the public sector and contributes to reduce the wage gap in the MW beginning period and the MW enforcement period.

(3) Considering the influences of other factors, the human capital is the main factor to cause the wage gap. For example, the estimated value of education as a component of explained differential (31.9\%) and of experience year as a component of explained differential is greatest (105.1\%) in the 1993-1995 period. The estimated value of education as a component of explained differential (37.8\%) and of experience year as a component of explained differential is greatest (129.3\%) in the 1998-2002 period. The estimated value of education as a component of explained differentials (125.7\%) and of experience year as a component of explained differentials is greatest (400.6\%) in the 2007-2013 period. These results showed that the greater proportions of high-level education and the seniority wage system, which is mostly implemented in the public sector, are the main factors to cause the wage gaps between the public and private sectors.

\section{Conclusions}

Chinese government has been officially implementing the MW system since 1993 and enforced MW policy in all of China since 2004. It is thought that the implementation of the MW policy contributes to increasing incomes of low-wage groups and reducing their poverty. In China, does the MW affect average wage and wage distribution? Particularly, does the MW affect the wages for low-wage groups? Does the spillover effect of MW exist in China? If it does, does there exist the difference of MW effects between the public and private sectors? To answer these questions, this study employs empirical studies using cross-section survey data-CHIPs 1995, 2002, 2007 and 2013, and divides periods into three periods - the MW beginning period (1993-1995), the MW performed period (1998-2002), and the MW enforcement period (2007-2013). Several major conclusions emerge.

First, comparatively, the overall impact of the MW on average wage at the MW policy beginning period is greater than the effect of the MW level on the average wage.

Second, the MW effects on average wage exist in both the public and private sectors. However, holding the other factors consistent, the MW effect on average wage is greater for the private sector than for the public sector.

Third, the overall effects of MW level on the low-wage group increased in the 2007-2013 period.

Fourth, the effects of MW on wage distribution are greater for the private sector than for the public sector in the three periods. Holding the other factors consistent, the impact of MW on the low-wage group for the private sector increased greatly than for the public sector in the 2007-2013 period.

Fifth, decomposition results indicated that the differences of distribution proportions, in regions with different MW levels, between the public and private sectors helped reduce the wage gaps, as did the MW effects on wage, which were greater for the private sector than for the public sector in the 1993-1995 and 2007-2013 periods. 
According to these empirical analyses, we can conclude that the MW implementation contributes to the rise in wage level for the low-wage groups in the public and private sectors. There are two points worthy of attention. First, the results revealed that the difference between the effects of MW on the public and the private sectors became greater for the low-wage group in the 2007-2013 period. The results might be caused by the reason that along with the MW implementation, the MW compliance problem was reduced. A comparison study on the MW compliance problem for the private sector and the public sector should be done in the future. Moreover, the results show that the effects of MW on average wage and wage distribution are greater for the private sector than for the public sector. Thus, the effects of MW level adjustment (rise in the MW levels) on labor force costswhich affect labor demand for the low-skill or low-education workers-might be greater for the private sector; hence, the negative effect on employment might be greater for the private sector than for the public sector. Thus, the MW effects on employment should be considered when the government decides to modify the MW levels.

Although this study utilized the repeated cross-section data (CHIPs) to analyze the impact of the Minimum Wage (MW) policy on average wage and wage distribution in urban China in the 1993-1995, the 1998-2002, and the 2007-2013 periods, and compared the MW effects between public and private sectors, there left the endogeneity and heterogeneity problems in the study. Panel data should be utilized to address these econometric problems in the future. Moreover, the results also showed that the greater proportions of high-level education and the seniority wage system, which is mostly implemented in the public sector, are the main factors to cause the wage gaps between the public and private sectors. Thus using the firm level survey data, the researches related to the effects of firm wage and employment systems also should be done in the future.

\section{Funding}

This research was supported by JSPS KAKENHI Grand Number JP16K03611.

\section{Note}

Data used for the study was provided by the Income Inequality Research Center, Beijing Normal University.

\section{References}

Bhorat, H., Kanbur, R., \& Stanwix, B. (2014). Estimating the Impact of Minimum Wages on Employment, Wage, and NonWage Benefits: The Case of Agriculture in South Africa. American Journal of Agriculture Economics, 96, $1402-1419$. http://dx.doi.org/10.1093/ajae/aau049

Blinder, A. S. (1973). Wage Discrimination: Reduced Form and Structural Estimation. The Journal of Human Resources, 8 , 436-455. http://dx.doi.org/10.2307/144855

Card, D., \& Krueger, A. (1995). Myth and Measurement: The New Economics of the Minimum Wage. Princeton, NJ: Princeton University Press.

Chen Ge, Demurger, S., \& Fournier, M. 陳戈, Demurger, S., Fournier, M. (2005). Wage Differentials and Ownership Structure of China’s Enterprises 中国企业的工资差异和所有制结构. World Economic Forum, 6, 11-31.

Demurger, S., Li, S., \& Yang, J. (2012). Earning Differentials between the Public and Private Sectors in China: Exploring Changes for Urban Local Residents in the 2002s. China Economic Review, 23, 138-153.

http://dx.doi.org/10.1016/j.chieco.2011.08.007

Di Junpeng, \& Han Qing 邸俊鹏, 韩清 (2015). The Income Effects of Minimum Wage Increase 最低工资标准提升的收 入效应研究. The Journal of Quantitative \& Technical Economics, 7, 90-103.

Dinkelman, T., \& Ranchhod, V. (2012). Evidence on the Impact of Minimum Wage Laws in an Informal Sector: Domestic Workers in South Africa. Journal of Development Economics, 99, 27-45. http://dx.doi.org/10.1016/j.jdeveco.2011.12.006

Gindling, T. H., \& Terrell, K. (2005). The Effect of Minimum Wages on Actual Wages in Formal and Informal Sectors in Costa Rica. World Development, 33, 1905-1921. http://dx.doi.org/10.1016/j.worlddev.2005.04.017

Hohberg, M., \& Lay, J. (2015). The Impact of Minimum Wages on Informal and Formal Labor Market Outcomes: Evidence from Indonesia. IZA Journal of labor \& Development, 4, 14. http://dx.doi.org/10.1186/s40175-015-0036-4

Jia Peng, \& Zhang Shiwei 贾朋, 张世伟 (2013). Spillover Effects of Minimum Wage Increase 最低工资标准提升的溢出 效应. Statistical Research, 30, 37-41.

Koenker, R. W., \& Bassett, G. J. (1978). Regression Quantile. Econometrica, 46, 33-50. http://dx.doi.org/10.2307/1913643 
Ma Shuang, Zhang Jie, \& Zhu Xi 马双, 张款, 朱喜 (2012). The Effect of Minimum Wage on Average Wage and Employment 最低工资对中国就业和工资水平的影. Economic Research Journal, 5, 132-146.

Ma, X. (2015). Economic Transition and Wage Differentials between Public and Private Sectors in China. China-USA Business Review, 14, 477-494.

Ma, X. (2016). Changes of Wage Structures in Chinese Public and Private Sectors: 1995-2007. Management Studies, 4, 113.

Neumark, D. (2001). The Employment Effects of Minimum Wages: Evidence from a Prespecified Research Design the Employment Effects of Minimum Wages. Industry Relation, 40, 121-144. http://dx.doi.org/10.1111/0019-8676.00199

Neumark, D., \& Wascher, W. (2004). Minimum Wages, Labor Market Institutions, and Youth Employment: A CrossNational Analysis. Industrial and Labor Relations Review, 57, 223-248. http://dx.doi.org/10.1177/001979390405700204

Neumark, D., Cunningham, W., \& Siga, L. (2006). The Effects of the Minimum Wage in Brazil on the Distribution of Family Incomes: 1996-2001. Journal of Development Economics, 80, 136-159. http://dx.doi.org/10.1016/j.jdeveco.2005.02.001

Neumark, D., Schweitzer, M., \& Wascher, W. (2004). Minimum Wage Effects throughout the Wage Distribution. The Journal of Human Resources, 39, 425-450. http://dx.doi.org/10.2307/3559021

Oaxaca, R. L. (1973). Male-Female Wage Differentials in Urban Labor Markets. International Economic Review, 14, 693709. http://dx.doi.org/10.2307/2525981

Ye Lingxiang, Li Shi, \& Luo Chuliang 叶祥林, 李实, 罗楚亮 (2011). Industrial Monopoly, Ownership and Enterprises Wage Inequality: An Empirical Research Based on the First National Economic Census of Enterprises Data 行业垄断, 所有制与企业工资收入差距一一基于第一次全国工业普查数据的实证研究. Management World, 4, 26-36.

Zhang Juwei, \& Xue Xinxin 张车伟, 薛欣欣 (2008). State and Non-State Sector Wage Differentials and Human Capital Contribution 国有部门和非国有部门工资差异与人力资本贡献. Economic Research Journal, 4, 15-25.

Submit or recommend next manuscript to SCIRP and we will provide best service for you:

Accepting pre-submission inquiries through Email, Facebook, LinkedIn, Twitter, etc.

A wide selection of journals (inclusive of 9 subjects, more than 200 journals)

Providing 24-hour high-quality service

User-friendly online submission system

Fair and swift peer-review system

Efficient typesetting and proofreading procedure

Display of the result of downloads and visits, as well as the number of cited articles

Maximum dissemination of your research work

Submit your manuscript at: http://papersubmission.scirp.org/ 